\title{
PENGARUH MULTIPLE LARGE SHAREHOLDER STRUCTURE, LEVERAGE, DAN INTELLECTUAL CAPITAL TERHADAP KINERJA PERUSAHAAN JASA NON KEUANGAN YANG TERDAFTAR DI BURSA EFEK INDONESIA
}

\author{
Nita Yulistiani \\ Institut Teknologi \& Bisnis Ahmad Dahlan \\ nitayulistiani39@gmail.com
}

Diterima 14 September 2020

Disetujui 9 Maret 2021

\begin{abstract}
This research is quantitative and examined the effect of multiple large shareholder structure, leverage, and intellectual capital on company performance using the ROE. The data is retrieved from financial statements of service companies, exclude the finance subsector, listed on the Indonesian Stock Exchange for the period 2014-2018. There are 36 companies and 171 data for the sample using the purposive sampling method. The method of analysis used is multiple linear regression. The result is that multiple large shareholder structure, leverage, and intellectual capital have significant effects simultaneously on non-finance company performance. Partially, multiple large shareholder structure, leverage, and intellectual capital have positive and significant effects on company performance. This research proves that company performance can be enhanced by maximizing multiple large shareholder structure roles as supervisors to decrease internal conflicts and represent the minority shareholders, keeping the leverage ratio to avoid default risk, and utilizing intellectual capital to advance the value-added of the company.
\end{abstract}

Keywords: Multiple Large Shareholder Structure; Leverage; Intellectual Capital; Company Performance

\section{PENDAHULUAN}

\subsection{Latar Belakang}

Dalam mengembangkan perusahaan, manajemen membutuhkan suatu tolok ukur dan informasi untuk mengetahui bagaimana suatu perusahaan tumbuh. Kinerja perusahaan dibutuhkan agar perusahaan dapat menilai perubahaan yang terjadi dalam sumber daya ekonomi, serta memprediksi masa depan melalui kapasitas produksi dari sumber daya yang digunakan (Orniati, 2009). Manajemen dapat mengukur kinerja perusahaan dengan menggunakan laporan keuangan sebagai sarana informasi karena memuat angka-angka yang dapat dijadikan standar pertumbuhan perusahaan dalam satu periode pelaporan.

Multiple large shareholder structure (selanjutnya disebut MLSS) merupakan suatu struktur dimana kepemilikan saham sebuah perusahaan dimiliki oleh satu atau lebih pemegang saham dengan tingkat kepemilikan saham yang cenderung tinggi. Penelitian tentang MLSS masih terhitung sedikit, khususnya yang membahas pengaruh MLSS terhadap kinerja perusahaan di Indonesia. Penelitian yang dibuat oleh Haryono et al. (2017) membahas tentang keberadaan MLSS dalam melakukan pengawasan secara efektif dan pengaruhnya terhadap kinerja perusahaan dengan proksi Tobin's Q dan return on assets (ROA). Dari hasil penelitian tersebut dapat dilihat MLSS berpengaruh negatif dan signifikan terhadap ROA, 
sedangkan pada Tobin's Q tidak berpengaruh. Namun, pada penelitian milik Attig et al. (2009) dan Luo et al. (2013) MLSS berpengaruh positif terhadap nilai perusahaan yang diukur menggunakan Tobin's Q. Berdasarkan perbedaan hasil penelitian tersebut, penulis merasa variabel MLSS menarik untuk diteliti lebih lanjut dan pengaruhnya terhadap kinerja perusahaan.

PT Agung Podomoro Land Tbk mendapatkan suntikan dana dengan total Rp 2,59 triliun untuk melunasi pembayaran Obligasi Berkelanjutan I Tahap III Tahun 2014 senilai Rp 451 miliar, Obligasi Berkelanjutan I Tahap IV Tahun 2015 senilai Rp 99 miliar, dan utang sindikasi perbankan sebesar Rp 1,17 triliun. Dana tersebut didapatkan dari perjanjian pengambilan saham baru yang ditandatangani oleh PT Indofica dan Trihatma Kusuma Haliman, serta perjanjian fasilitas pinjaman dengan Credit Opportunities II Pte. Limited. Alhasil, saham Agung Podomoro menjadi naik hingga 11,29\% selama dua hari sejak kedua kontrak tersebut ditekan pada 24 September 2019 (katadata.co.id, 2019). Sedangkan pada beberapa bulan sebelumnya, PT Bakrie Telecom Tbk yang lebih dikenal sebagai operator Esia memiliki total liabilitas mencapai Rp 16,13 triliun, dengan Rp 10,09 triliun untuk liabilitas jangka pendek dan Rp 6,03 triliun untuk liabilitas jangka panjang. Terdapat selisih yang jauh jika dibandingkan dengan nilai liabilitas pada tahun 2010 yang tercatat sebesar Rp 7,16 triliun. Hal tersebut membuat saham Bakrie Telecom disuspensi oleh Bursa Efek Indonesia (BEI) sejak 27 Mei 2019. Bakrie Telecom dinilai tidak mampu membayar utangnya kepada kreditur dan investor (katadata.co.id, 2019).

Dari dua kasus diatas, dapat disimpulkan bahwa kemampuan perusahaan dalam melunasi kewajibannya sangat penting untuk menjaga integritas perusahaan dihadapan kreditur maupun pemegang saham. Perusahaan yang berintegritas dapat memupuk kepercayaan kreditur dan investor sehingga perusahaan dapat terus hidup. Dengan menganalisis rasio leverage, kinerja perusahaan dapat dinilai dari segi pengaruh penggunaan pinjaman terhadap peningkatan kinerja perusahaan (Ludijanto et al., 2014). Rasio leverage yang menggunakan perbandingan liabilitas dengan total aset mempunyai dampak negatif terhadap kinerja perusahaan. Hal tersebut membuktikan bahwa semakin tinggi rasio debt to asset, semakin tinggi sumber dana yang dikeluarkan untuk membayar utang perusahaan (Azis \& Hartono, 2017).

Dalam dunia perekonomian yang baru, konsep intellectual capital merujuk kepada karyawan yang mempunyai kemampuan untuk mengubah dan membaurkan ilmu pengetahuan kedalam barang dan jasa yang menciptakan sebuah nilai. Penciptaan nilai ini sudah disadari sejak lama dalam sebuah mata rantai kepuasan antara pelanggan, karyawan, dan pemilik perusahaan. Pelanggan puas akan produk atau jasa yang disediakan perusahaan, lalu perusahaan meraih laba yang tinggi dan memberikan kepuasan kepada pemilik perusahaan. Pemilik perusahaan yang puas akan lebih menginvestasikan kepada sumber daya manusia, tidak selalu dengan memberikan insentif berlebih, tapi dengan memberikan pelatihan, peralatan, dan menciptakan kondisi lingkungan kerja agar suasana menjadi produktif dan menyenangkan bagi karyawan. Hal-hal tersebut membuat karyawan menjadi senang berkontribusi dalam kelangsungan hidup perusahaan (Rust et al., 1994: 134).

Dari latar belakang diatas, penulis ingin meriset lebih lanjut mengenai pengaruh MLSS, leverage, dan intellectual capital terhadap kinerja perusahaan. Sejauh ini belum ada penelitian yang menggabungkan ketiga unsur tersebut untuk mengetahui kinerja perusahaan. Penulis memilih perusahaan jasa non keuangan yang terdaftar di Bursa Efek Indonesia (BEI) sebagai sampel berdasarkan fenomena yang terdapat dalam latar belakang. Perusahaan jasa juga dianggap lebih mengedepankan sumber daya manusia yang mumpuni karena berhubungan langsung dengan pelanggan apabila dilihat dari mata rantai kepuasan dalam 
penciptaan nilai. Atas saran dari penelitian Haryono et al. (2017) penulis menggunakan ROE sebagai ukuran kinerja perusahaan. Semoga penelitian ini dapat memberikan informasi kepada manajemen untuk mengembangkan intellectual capital sebagai modal dan peran pemegang saham terbesar sebagai dewan pengawas untuk memaksimalkan kinerja perusahaan. Selain itu, penelitian ini juga diharapkan dapat memaparkan informasi lebih lanjut kepada pihak internal perusahaan untuk memperhatikan penggunaan liabilitas dalam mengembalikan kekayaan perusahaan. Penulis juga berharap penelitian ini dapat menjadi referensi bagi penelitian berikutnya serta menambah literatur penelitian akuntansi dengan fokus topik seputar MLSS, leverage, dan intellectual capital.

\subsection{Rumusan Masalah}

Berdasarkan latar belakang yang dibahas sebelumnya, adapun rumusan masalah penelitian ini sebagai berikut.

1. Apakah multiple large shareholder structure berpengaruh terhadap kinerja perusahaan jasa non keuangan yang terdaftar di BEI pada 2014-2018?

2. Apakah leverage berpengaruh terhadap kinerja perusahaan jasa non keuangan yang terdaftar di BEI pada 2014-2018?

3. Apakah intellectual capital berpengaruh terhadap kinerja perusahaan jasa non keuangan yang terdaftar di BEI pada 2014-2018?

4. Apakah multiple large shareholder structure, leverage, dan intellectual capital secara simultan berpengaruh terhadap kinerja perusahaan jasa non keuangan yang terdaftar di BEI pada 2014-2018?

\subsection{Landasan Teori}

\subsubsection{Teori Agensi}

Teori agensi dicetuskan oleh Jensen \& Meckling pada 1976. Teori tersebut mendeskripsikan struktur dan mendasari pentingnya pemisahan peran sebagai mekanisme kontrol di perusahaan. Pemisahan peran ini terdiri dari manajemen sebagai agen yang menjalankan perusahaan dan pemegang saham sebagai pemilik perusahaan yang mengawasi agen (Adelopo et al., 2019). Akibatnya akan muncul biaya dari perbedaan informasi dan kepentingan antara pemilik dan agen yang disebut sebagai agency cost. Dengan adanya agency cost, biaya yang seharusnya dapat digunakan untuk produktivitas perusahaan justru menambah beban administrasi yang mampu memberikan dampak dalam laporan laba rugi perusahaan.

Masalah keagenan juga tidak hanya sebatas antara manajemen dan pemilik, namun dapat menjadi masalah antar pemilik. Kepemilikan perusahaan dapat terdiri dari satu pemilik saham terbesar maupun lebih. Hillman et al. (2000) dan Pearce \& Zahra (1992) dalam Adelopo et al. (2019) berpendapat bahwa hal tersebut menimbulkan konflik dalam menentukan struktur dan komposisi dewan direksi yang bertanggungjawab terhadap keputusan mengenai alokasi pendanaan dan masa depan perusahaan. Konflik internal ini pun dapat menyudutkan pemilik saham minoritas karena tidak dapat berkontribusi langsung dalam pengambilan keputusan dikarenakan pemilik saham terbesar saling berkoalisi satu sama lain.

\subsubsection{Teori Stakeholder}

Teori stakeholder memberikan gambaran bahwa organisasi mengungkapkan informasi yang berhubungan dengan kinerja lingkungan, sosial, dan intelektual secara sukarela dihadapan stakeholder (Ulum, 2017: 36). Goh dan Lim (2004) dalam Fatima (2012), berpendapat bahwa seluruh pihak yang berkepentingan harus memperoleh informasi strategis 
yang berkaitan dengan modal intelektual agar memenuhi ekspektasi stakeholder terhadap perusahaan. Berdasarkan pengelolaan intellectual capital yang dilakukan peru-sahaan, maka akan timbul pengungkapan sebuah nilai tambah. Sehingga diharapkan terjadi peningkatan kepercayaan stakeholder dan pengurangan risiko ketidakpastian dari investor.

\subsubsection{Penelitian Terdahulu dan Hipotesis}

Multiple large shareholder structure diyakini berperan sebagai dewan pengawas untuk mengurangi konflik diantara para pemegang saham, sehingga diharapkan dapat membuat keputusan yang tepat terkait masa depan perusahaan dan tidak merugikan pemegang saham minoritas. Attig et al. (2009) mengatakan bahwa multiple large shareholder structure (MLSS) dimiliki suatu perusahaan yang susunan kepemilikan sahamnya terdiri dari beberapa pemilik saham dengan percentage of ownership di atas $10 \%$, selain pemilik saham terbesarnya. Hasil penelitiannya juga menyatakan bahwa MLSS dinilai mampu sebagai bentuk pengawasan kepada pemegang saham sehingga dapat mengurangi silang pendapat antar para pemegang saham (Haryono et al., 2017). MLSS juga berperan positif dalam menambah nilai perusahaan dengan catatan dilihat dari identitas struktur pemilik saham dan juga ukuran perusahaan tersebut (Maury \& Pajuste, 2005).

Penelitian yang dilakukan Maury \& Pajuste (2005), Attig et al. (2009), dan Luo et al. (2013) menunjukkan bahwa terdapat pengaruh positif pada nilai perusahaan yang diukur menggunakan Tobin's Q. Penelitian Haryono et al. (2017) menunjukkan hal sebaliknya bahwa MLSS berpengaruh negatif terhadap kinerja perusahaan yang diukur dengan menggunakan ROA, sedangkan dengan Tobin's Q hasilnya adalah tidak menunjukkan pengaruh apapun. Atas saran penelitian Haryono et al. (2017) sebagai referensi, penulis ingin meneliti kembali apakah terdapat pengaruh MLSS terhadap ROE sebagai ukuran kinerja perusahaan. Sehingga dalam penelitian ini penulis mengajukan $\mathrm{H}_{1}$ sebagai berikut.

\section{perusahaan}

H1: Multiple large shareholder structure berpengaruh positif terhadap kinerja

Perusahaan dapat dikatakan stabil apabila manajemen dapat memaksimalkan penggunaan dana untuk membiayai aktivitas operasional perusahaan. Kemampuan tersebut biasa disebut dengan leverage. Terdapat dua jenis leverage: operating leverage dan financial leverage. Operating leverage menandakan bahwa biaya operasional yang masih berjalan adalah biaya tetap yang sesuai dengan besarnya volume produksi, sehingga mempengaruhi naik turunnya laba jika terjadi perubahan dalam volume produksi. Sedangkan financial leverage terjadi ketika struktur modal sebuah perusahaan didapat dari pinjaman pihak ketiga dengan tingkat bunga tetap, dengan prinsip seperti operating leverage (Helfert, 1994: 217).

Rasio leverage digunakan untuk menghitung seberapa baik kinerja perusahaan dalam mengelola dana untuk membiayai operasionalnya. Penelitian Isbanah (2015) dan Azis \& Hartono (2017) menunjukkan bahwa rasio leverage yang menggunakan DAR berpengaruh negatif terhadap kinerja perusahaan. Sedangkan penelitian Ludijanto et al. (2014) memperlihatkan terdapat pengaruh positif DAR pada kinerja perusahaan. Azis \& Hartono mengungkapkan bahwa perusahaan dengan DAR yang tinggi dapat menurunkan kinerja perusahaan karena perusahaan harus mengeluarkan dana yang lebih untuk melunasi utangnya serta menghadapi risiko gagal bayar (default) yang lebih besar. Berdasarkan hasil penelitian Isbanah (2015) serta Azis \& Hartono (2017) penulis mengajukan $\mathrm{H}_{2}$ sebagai berikut.

\section{$\mathrm{H}_{2}$ : Leverage berpengaruh negatif terhadap kinerja perusahaan}


Intellectual capital dianggap dapat meningkatkan kinerja perusahaan melalui penciptaan nilai tambah dari ketiga unsur intellectual capital: human capital, structural capital, dan customer capital. Human capital merupakan modal yang berasal dari pengetahuan individu yang dalam konteks ini diwakilkan oleh karyawan perusahaan. Komponen ini mendasari ide-ide kreatif dan inovasi dari pengetahuan yang dimiliki karyawan. Structural capital meliputi modal intelektual non-human yang dapat terdiri dari program dan basis data yang digunakan, struktur dan budaya organisasi, maupun sistem yang terintegrasi antar divisi, dan segala sesuatu yang nilainya lebih tinggi dari nilai materialnya. Customer capital mencakup hubungan antar perusahaan dengan pihak eksternal. Komponen ini dapat meliputi pengetahuan dari marketing, hubungan perusahaan dengan pihak pelanggan, pelayanan yang diberikan kepada pelanggan, maupun relasi perusahaan dengan pemasok dan pemerintah (Herman, 2016). Dalam penelitian yang dilakukan Fatima (2012) pada perusahaan sektor farmasi dan jasa di Indonesia, terdapat pengaruh yang positif antara intellectual capital terhadap kinerja perusahaan dan menjadi salah satu variabel penting. Penelitian lain yang dilakukan oleh Chen et al. (2005), Sofie et al. (2012), Dwipayani (2014), dan Astuti et al. (2019) juga menunjukkan hasil serupa yakni intellectual capital berpengaruh positif terhadap kinerja perusahaan yang diukur menggunakan VAIC ${ }^{\text {TM}}$. Demikian penulis mengajukan $\mathrm{H}_{3}$ sebagai berikut.

\section{H3: Intellectual capital berpengaruh positif terhadap kinerja perusahaan.}

Banyak faktor yang dapat mempengaruhi kinerja perusahaan, baik itu dari pemegang saham, manajemen, maupun kombinasi keduanya. MLSS sebagai pihak yang mewakili pemegang saham minoritas sehingga mampu untuk menjaga keseimbangan diantara pemegang saham agar tidak saling berkoalisi untuk kepentingan pribadi. Perusahaan yang mampu mengatur sumber dananya dengan baik akan memberikan nilai tambah dihadapan kreditur maupun investor. Selain itu perusahaan yang lebih mengedepankan knowledge-based dapat meningkatkan kinerja perusahaan karena diyakini mampu mengelola ketiga modal yang menjadi kunci pertumbuhan laba perusahaan. Dari ketiga variabel tersebut, penulis meyakini bahwa secara bersama-sama terdapat pengaruh pada kinerja perusahaan. Sehingga penulis mengajukan $\mathrm{H}_{4}$ sebagai berikut.

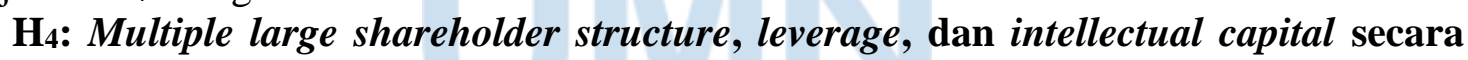
simultan berpengaruh terhadap kinerja perusahaan.

Kerangka pemikiran untuk penelitian ini dapat dilihat pada gambar di bawah ini.

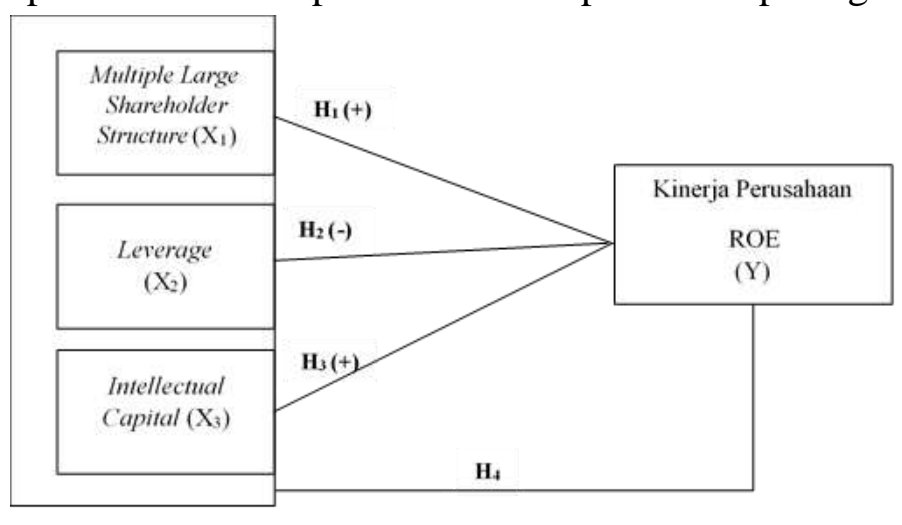

Gambar 1 Kerangka Pemikiran

Sumber: Dari beberapa penelitian dengan modifikasi 


\section{METODOLOGI PENELITIAN}

Penelitian ini termasuk ke dalam penelitian kuantitatif korelasional. Penelitian bersifat kuantitatif karena menggunakan metode analisis data sekunder dengan variabel yang bersifat numerik dan diolah dengan teknik statistik (Sudaryono, 2018: 92). Lebih lanjut Sudaryono (2018: 89) memaparkan penelitian korelasional sebagai penelitian yang mencari hubungan antara dua variabel dan seberapa jauh korelasi antara variabel yang diteliti.

Teknik pengumpulan data dalam penelitian yang dilakukan penulis yaitu dokumentasi. Dokumen yang digunakan dalam penelitian ini adalah dokumen tertulis berupa laporan keuangan. Laporan keuangan termasuk dalam data sekunder, yakni data yang tidak diolah oleh peneliti secara langsung. Laporan keuangan perusahaan jasa non keuangan diperoleh dari situs web idx.co.id, idnfinancials.com, maupun web resmi perusahaan. Periode laporan keuangan dari 2014-2018. Penilitian ini menggunakan purposive sampling untuk menentukan kriteria sampel. Metode ini dipilih karena penulis dapat memilah sampel sesuai dengan kriteria yang diinginkan (Herman, 2016). Kriteria sampel ini merujuk pada kriteria sampel penelitian Haryono, et al. (2017) dengan beberapa perubahan. Tabel berikut memuat kriteria sampel yang penulis gunakan dalam penelitian.

Tabel 1. Kriteria Sampel Penelitian

\begin{tabular}{|l|c|}
\hline \multicolumn{1}{|c|}{ Keterangan } & Jumlah \\
\hline Perusahaan jasa non keuangan yang terdaftar di BEI tahun 2014 & 207 \\
\hline Perusahaan jasa non keuangan yang termasuk BUMN & $(8)$ \\
\hline $\begin{array}{l}\text { Perusahaan jasa non keuangan yang tidak menerbitkan laporan keuangan } \\
\text { periode 2014-2018 }\end{array}$ & $(10)$ \\
\hline $\begin{array}{l}\text { Perusahaan jasa non keuangan yang menggunakan mata uang selain } \\
\text { rupiah dalam laporan keuangan periode 2014-2018 }\end{array}$ & $(27)$ \\
\hline $\begin{array}{l}\text { Perusahaan jasa non keuangan yang mengalami kerugian periode 2014- } \\
\text { 2018 }\end{array}$ & $(70)$ \\
\hline Perusahaan jasa non keuangan yang tidak memenuhi kriteria penelitian & $(56)$ \\
\hline Total perusahaan yang diteliti & $\mathbf{3 6}$ \\
\hline Total sampel yang diteliti (dikali 5 periode laporan keuangan) & $\mathbf{1 8 0}$ \\
\hline Sampel yang dikeluarkan karena data outlier & $\mathbf{1 7 1}$ \\
\hline Total sampel yang diteliti & 9 \\
\hline
\end{tabular}

Variabel MLSS (X1) diukur berdasarkan persentase kepemilikan saham kedua terbesar dalam struktur modal saham sebesar lebih dari $10 \%$ dengan rumus sebagai berikut (Haryono et al., 2017).

$$
\text { MLSS }=\frac{\% \text { pemegang saham kedua terbesar }}{\% \text { pemegang saham pertama terbesar }}
$$

Variabel leverage (X2) digunakan untuk mengukur tingkat penggunaan dana dari kreditur dalam membiayai aktivitas operasional perusahaan. Variabel ini menggunakan rasio debt to asset untuk mengukur pengaruh leverage terhadap kinerja perusahaan (Isbanah, 2015; Ludijanto et al., 2014; Azis \& Hartono, 2017).

$$
\text { Leverage }=\frac{\text { Total Liabilitas }}{\text { Total Aset }}
$$

Variabel intellectual capital (X3) diukur menggunakan koefisien yang mencari nilai tambah dari unsur modal intelektual atau VAICTM milik Pulic (Chen et al., 2005; Fatima, 2012; Astuti et al., 2019). 


\section{$\mathrm{VAIC}^{\mathrm{TM}}=\mathrm{VACA}+\mathrm{VAHU}+\mathrm{STVA}$}

Variabel kinerja perusahaan (Y) diukur menggunakan ROE yang diformulasikan sebagai berikut.

$$
\text { ROE }=\frac{\text { Laba Bersih setelah Pajak }}{\text { Total Ekuitas }}
$$

Analisis data menggunakan metode regresi linear berganda. Tujuan analisis ini adalah untuk mendapatkan bukti atas hubungan kausal yang terdiri dari dua atau lebih variabel independen dengan satu variabel dependen. Hingga saat ini pengujian yang dapat dikembangkan lebih lanjut adalah model linear dengan maksimum 4 variabel bebas, karena jika lebih dari itu sukar untuk diuji kelinearannya (Kesumawati et al., 2018: 127-128). Agar mendapatkan hasil analisis regresi yang baik digunakan uji asumsi klasik berupa uji normalitas, uji multikolinearitas, uji heteroskedastisitas, uji autokorelasi, dan uji linieritas. Sedangkan untuk pengujian hipotesis terdiri dari koefisien determinasi, uji F (uji simultan), dan uji t (uji parsial). Persamaan regresi linear berganda yang penulis gunakan adalah sebagai berikut.

$$
\mathbf{Y}=\alpha+\beta_{1} X_{1}+\beta_{2} X_{2}+\beta_{3} X_{3}+\varepsilon
$$

Keterangan:

$\mathrm{X}_{1}=$ Multiple Large Shareholder Structure

$\mathrm{X}_{2}=$ Leverage

$\mathrm{X}_{3}=$ Intellectual Capital

$\mathrm{Y}=$ Return On Equity

$\alpha=$ konstanta

$\beta=$ koefisien regresi

$\varepsilon=$ error

\section{HASIL PENELITIAN DAN DISKUSI} 3.1 Analisis Statistik Deskriptif

Tabel 2. Analisis Deskriptif Data

\begin{tabular}{|c|c|r|r|r|c|}
\hline Variabel & $\mathrm{N}$ & Minimum & Maksimum & $\begin{array}{c}\text { Rata- } \\
\text { Rata }\end{array}$ & $\begin{array}{c}\text { Std. } \\
\text { Deviasi }\end{array}$ \\
\hline MLSS & 171 & 0,1858 & 1,0000 & 0,574946 & 0,2588155 \\
\hline DAR & 171 & 0,0003 & 0,8403 & 0,411751 & 0,1874786 \\
\hline VAIC & 171 & 1,0786 & 49,2328 & 4,336064 & 4,9450813 \\
\hline ROE & 171 & 0,0004 & 0,2352 & 0,090904 & 0,0578152 \\
\hline \multicolumn{7}{|c}{ Sumber: Data diolah SPSS 25 }
\end{tabular}

Statistik deskriptif adalah statistik yang dipakai dalam melakukan analisis data dengan merefleksikan data yang telah terkumpul tanpa generalisasi. Statistik ini hanya mendeskripsi data sampel tanpa membuat suatu asumsi maupun kesimpulan tertentu (Sudaryono, 2018: 348). Dari 171 sampel yang diteliti, variabel Multiple Large Shareholder Structure (MLSS) memiliki nilai rata-rata sebesar 0,574946 dan standar deviasi 0,2588155 yang menunjukkan bahwa nilai MLSS sampel perusahaan jasa non keuangan rata-rata sebesar 57,5\% dengan nilai sebaran data sebesar $25,88 \%$ pada perusahaan jasa non keuangan periode 2014-2018. Variabel kedua yaitu leverage (LEV) memiliki nilai rata-rata sebesar 0,411751 dan standar deviasi 
sebesar 0,1874786. Hal tersebut menunjukkan bahwa rasio debt to asset pada sampel perusahaan jasa non keuangan rata-rata sebesar $41,18 \%$ dengan sebaran data sebesar $18,75 \%$ selama periode penelitian. Variabel Intellectual Capital (VAIC) memiliki nilai rata-rata 4,336064 dan standar deviasi 4,9450813. Hal ini menunjukkan bahwa nilai VAIC (Value Added Intellectual Coefficient) sampel perusahaan jasa non keuangan rata-rata sebesar 4,34 dengan nilai sebaran data sebesar 4,95 pada periode penelitian.Variabel dependen ROE memiliki nilai rata-rata 0,090904 dan standar deviasi 0,0578152. Hal tersebut menunjukkan bahwa sampel perusahaan jasa non keuangan memiliki rasio ROE rata-rata sebesar 9,1\% dengan nilai sebaran data sebesar $5,78 \%$ pada periode penelitian.

\subsection{Uji Asumsi Klasik}

\section{Tabel 3. Uji Normalitas}

\begin{tabular}{l|c|c} 
& $\mathrm{N}$ & Asymp. Sig. \\
\hline Uji Normalitas sebelum outlier & 180 & 0,000 \\
\hline Uji Normalitas setelah outlier & 171 & 0,200 \\
\hline \multicolumn{2}{c}{ Sumber: Data diolah SPSS 25}
\end{tabular}

Sampel awal yang digunakan berasal dari 180 laporan keuangan perusahaan jasa non keuangan periode 2014-2018. Nilai signifikansi uji normalitas adalah 0,000 > 0,05 sehingga menunjukkan bahwa data tidak normal. Karenanya penulis memutuskan untuk menghilangkan data yang tidak normal tersebut dengan menggunakan uji outlier. Uji outlier yang dipilih adalah metode Boxplot.

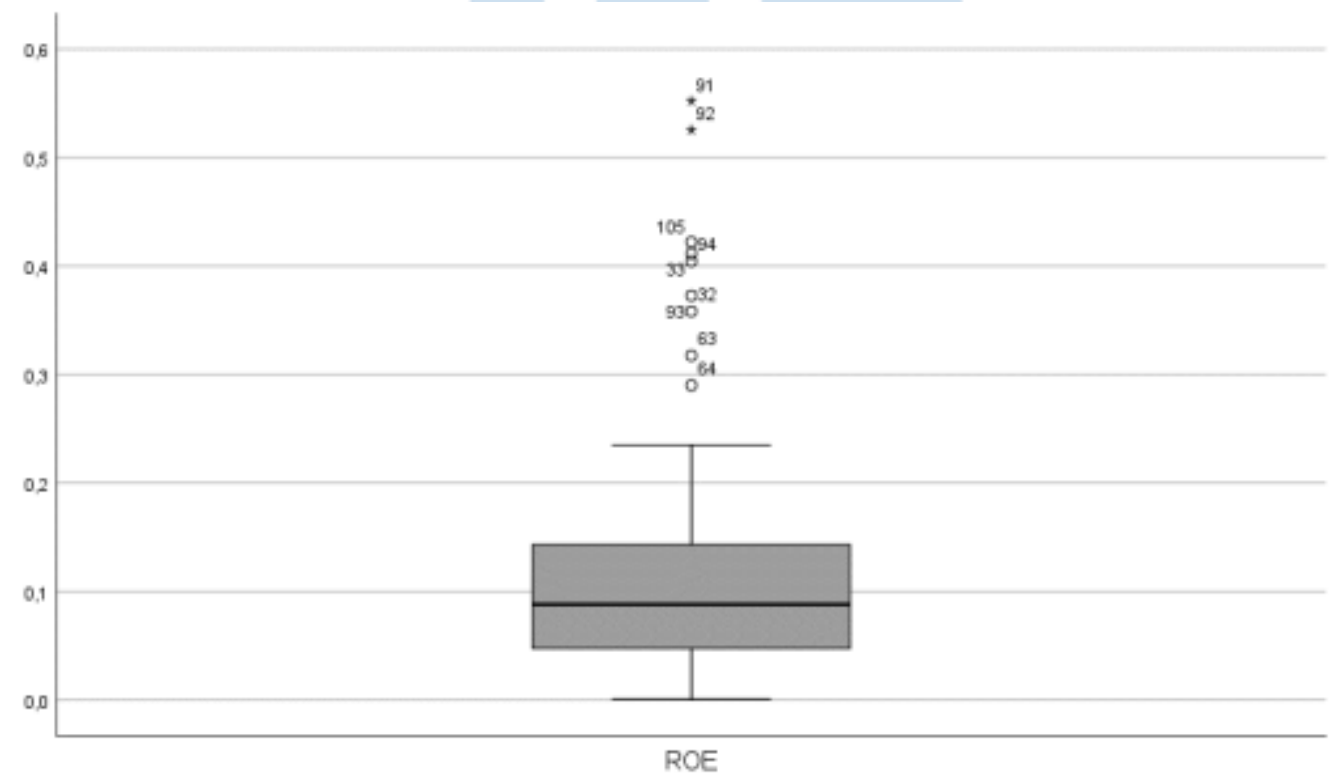

\section{Gambar 2 Boxplot variabel ROE}

Sumber: SPSS 25

Dari gambar diatas diperoleh 9 data yang masuk dalam uji outlier Boxplot. Data tersebut kemudian dihapus sehingga menghasilkan 171 sampel yang akan diteliti lebih lanjut. Setelah dilakukan outlier, nilai signifikansi yang diperoleh adalah 0,200. Hal tersebut menunjukkan bahwa nilai signifikansi yang didapat > 0,05 sehingga dapat dikatakan bahwa data yang digunakan untuk penelitian termasuk normal dan baik digunakan dalam model regresi. 
Tabel 4. Uji Multikolinearitas

\begin{tabular}{|c|c|c|}
\hline \multirow{2}{*}{ Variabel } & \multicolumn{2}{|c|}{ Collinearity Statistics } \\
\cline { 2 - 3 } & Tolerance & VIF \\
\hline MLSS & 0,969 & 1,032 \\
\hline DAR & 0,827 & 1,209 \\
\hline VAIC & 0,807 & 1,240 \\
\hline
\end{tabular}

Sumber: Data diolah SPSS

Pada tabel 4 dapat dilihat untuk variabel MLSS, DAR, dan VAIC memiliki nilai tolerance mendekati $<1$ dan nilai VIF $<10$. Hal tersebut menjelaskan bahwa variabelvariabel yang digunakan dalam penelitian bebas dari multikolinearitas sehingga baik digunakan dalam model regresi.

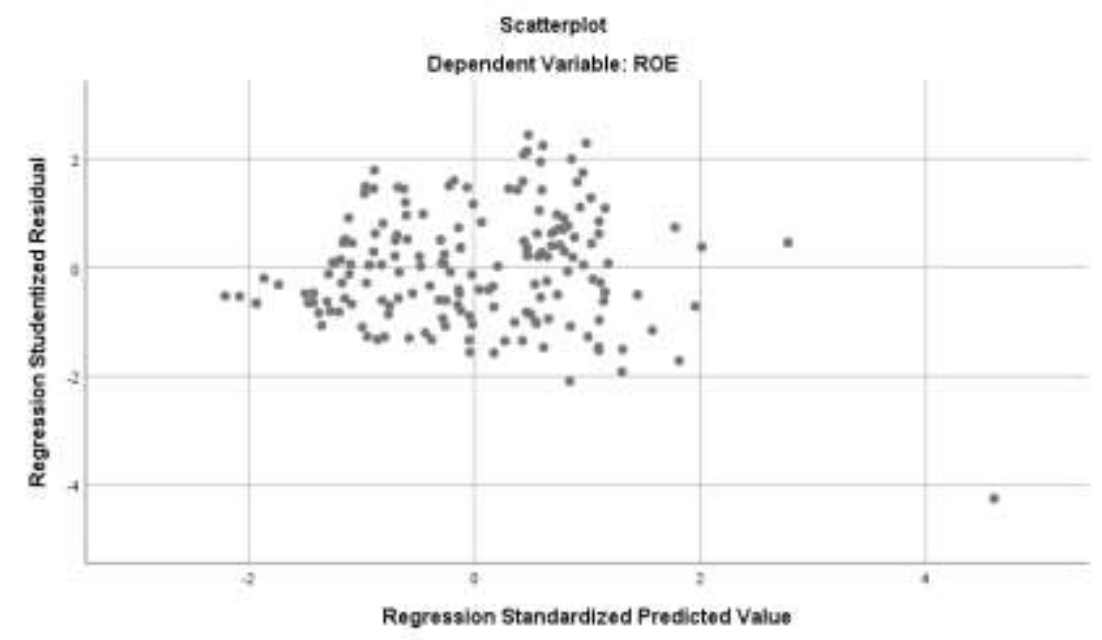

Gambar 3. Grafik Uji Heteroskedastisitas

Sumber: SPSS 25

Pada grafik uji hetersokedastisitas, terlihat data menyebar dan tidak menunjukkan pola tertentu atau menumpuk di titik tertentu. Hal ini membuktikan bahwa tidak terjadi gejala heteroskedastisitas dan data baik digunakan dalam model regresi.

Tabel 5. Uji Autokorelasi

\begin{tabular}{l|c|c|c} 
& \multicolumn{1}{c}{$\begin{array}{c}\text { Durbin- } \\
\text { Watson }\end{array}$} & \multicolumn{1}{c}{$\mathrm{dL}$} & $\mathrm{dU}$ \\
\hline Uji Autokorelasi sebelum transformasi & 1,050 & 1,7143 & 1,7856 \\
\hline Uji Autokorelasi setelah transformasi & 1,953 & 1,7143 & 1,7856 \\
\hline \multicolumn{4}{l}{ Sumber: Data diolah SPSS 25 }
\end{tabular}

Pada tabel 5 dapat dilihat bahwa nilai Durbin-Watson (DW) yang didapat adalah sebesar 1,050. Nilai dL dan dU yang diperoleh untuk data sejumlah 171 dan 3 variabel independen masing-masing adalah 1,7143 dan 1,7856. Jika dibandingkan, nilai DW sebesar $1,050<$ nilai dL sebesar 1,7143. Dengan kata lain, terjadi autokorelasi positif pada model penelitian dan diperlukan penanganan agar data bebas autokorelasi. Treatment yang diberikan 
adalah dengan transformasi variabel menggunakan metode estimasi $\rho$ (rho) yang didapatkan dengan mengetahui nilai koefisien dari residual atau error (Putri, 2015). Setelah dilakukan transformasi, nilai DW mengalami kenaikan menjadi 1,953. Nilai DW > nilai dU dan masih dibawah nilai 4-dU sehingga telah bebas dari gejala autokorelasi positif.

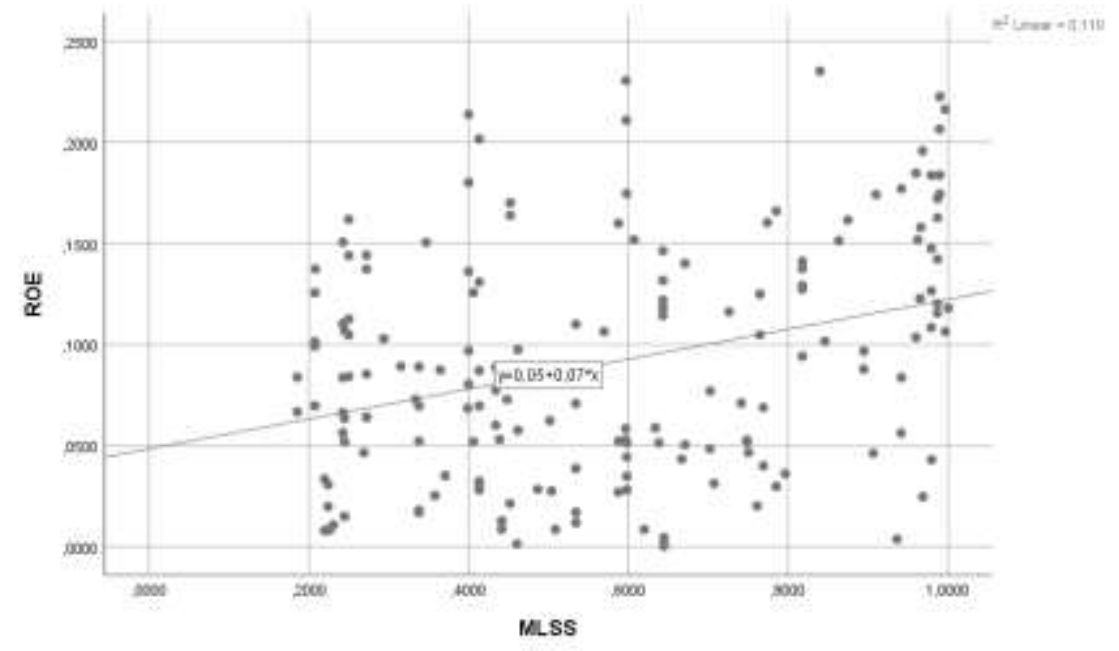

Gambar 4 Scatter Plot variabel MLSS dengan ROE

Sumber: SPSS 25

Pada gambar 4 terlihat garis regresi yang meninggi ke kanan atas. Hal tersebut mengindikasikan bahwa terdapat linieritas antara variabel MLSS dan ROE. Sehingga dapat dijelaskan bahwa semakin tinggi rasio MLSS yang diperoleh semakin tinggi kemungkinan ROE yang dihasilkan.

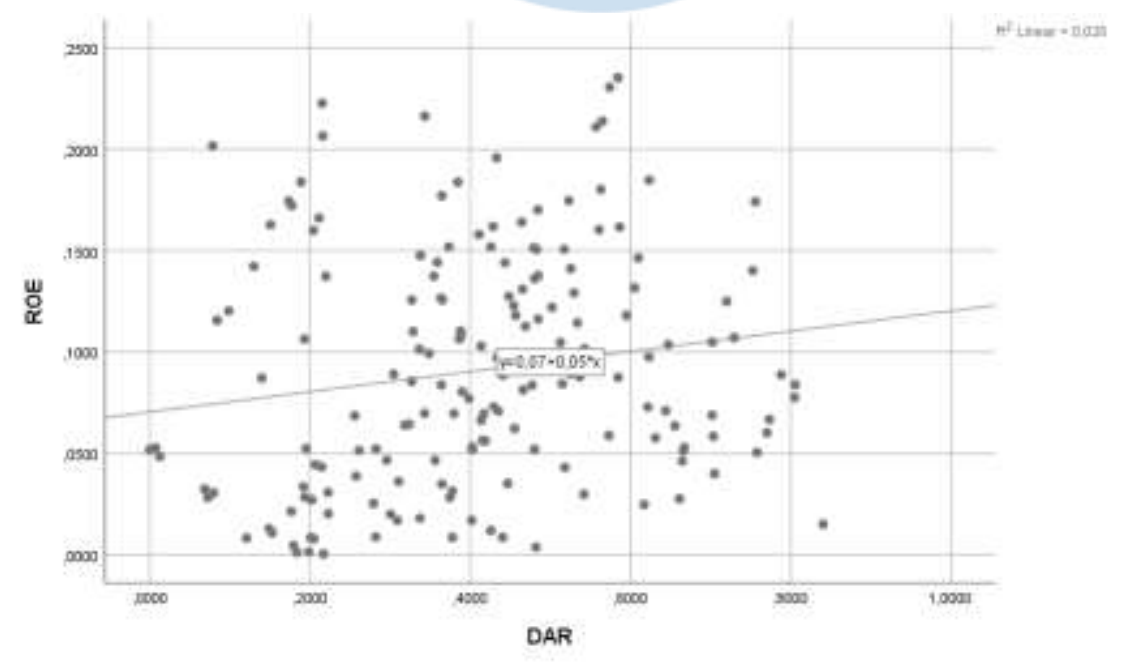

Gambar 5 Scatter Plot variabel DAR dengan ROE Sumber: SPSS 25

Pada gambar 5 terlihat garis regresi yang meningkat ke arah kanan atas. Hal ini mengindikasikan bahwa terdapat linieritas antara variabel leverage dengan ROE. Dengan kata lain, semakin tinggi DAR yang dihasilkan semakin tinggi kemungkinan ROE yang didapatkan. 


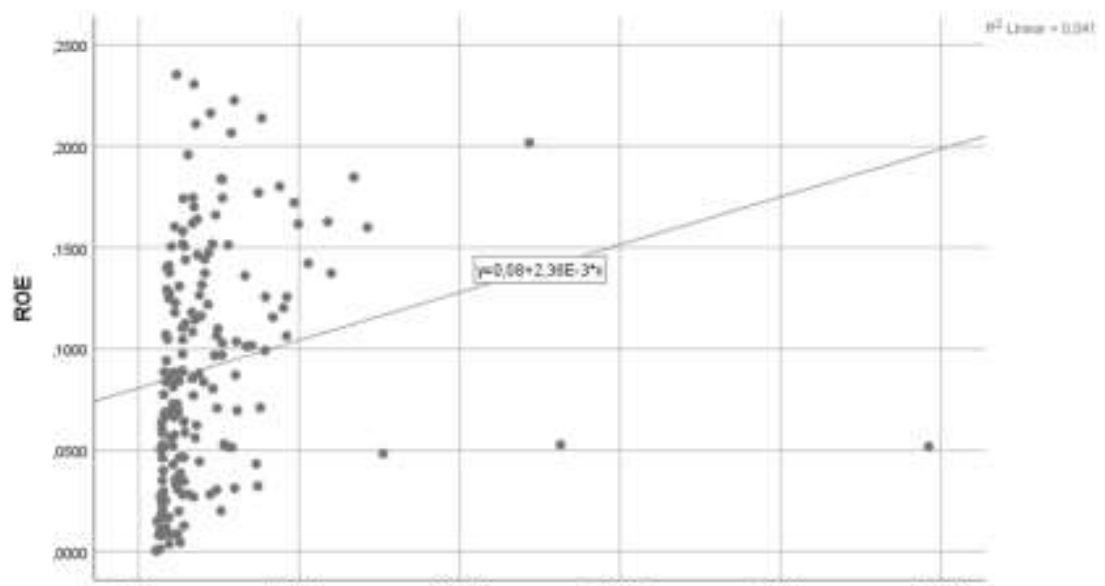

Gambar 6 Scatter Plot variabel VAIC dengan ROE

Sumber: SPSS 25

Pada gambar 6 terlihat garis regresi yang meningkat ke sisi kanan atas. Hal tersebut mengindikasikan bahwa terdapat linieritas pada variabel intellectual capital dengan ROE. Sehingga dapat disebutkan bahwa semakin tinggi skor VAIC yang dihasilkan semakin tinggi kemungkinan ROE yang didapatkan.

\subsection{Koefisien Determinasi \& Uji Hipotesis}

Tabel 6. Koefisien Determinasi, Uji F, \& Uji t

\begin{tabular}{cccc} 
Variabel & Koefisien & $\mathrm{t}$ & Sig. \\
\hline (Constant) & 0,007 & 0,451 & 0,653 \\
MLSS & 0,064 & 4,057 & 0,000 \\
DAR & 0,083 & 3,503 & 0,001 \\
VAIC & 0,003 & 3,432 & 0,001 \\
\hline Koefisien determinasi $\left(\mathrm{R}^{2}\right)$ & & 0,192 \\
\hline Sig. of F & & 0,000 \\
\hline
\end{tabular}

Pada tabel 6 dapat dilihat nilai $R^{2}$ yang diperoleh sebesar 0,192 . Hal ini menunjukkan bahwa persentase hasil penelitian pengaruh variabel MLSS, leverage, dan intellectual capital terhadap kinerja perusahaan sebesar 19,2\%. Sementara 80,8\% lainnya dipengaruhi oleh variabel lain diluar penelitian yang dilakukan. Nilai signifikansi dari uji $\mathrm{F}$ yang diperoleh sebesar 0,000 dan < 0,05. Hal ini menjelaskan bahwa variabel MLSS, leverage, dan intellectual capital secara simultan berpengaruh terhadap kinerja perusahaan pada sampel perusahaan jasa non keuangan periode 2014-2018. Dengan kata lain, hipotesis keempat diterima.

Persamaan regresi linear berganda untuk penelitian ini menggunakan nilai koefisien yang tertera pada tabel 6 adalah sebagai berikut.

$$
\text { ROE }=0,007+0,064 \mathrm{MLSS}+0,083 \mathrm{DAR}+0,003 \mathrm{VAIC}+\varepsilon
$$

Dari persamaan diatas dapat dilihat terdapat nilai konstanta sebesar 0,007. Sehingga dapat dikatakan bahwa jika seluruh variabel independen adalah 0 (nol), maka akan terjadi peningkatan nilai variabel dependen atau ROE sebesar 0,007.

Variabel MLSS memiliki nilai koefisien sebesar 0,064 dan nilai signifikansi sebesar 0,000. Hal tersebut menjelaskan bahwa terjadi kenaikan 0,064 pada variabel ROE untuk setiap bertambahnya 1 satuan variabel MLSS. Nilai signifikansi sebesar $0,000<0,05$ 
menunjukkan bahwa variabel tersebut mempunyai pengaruh yang signifikan. Dengan nilai koefisien positif, maka dapat disimpulkan bahwa terdapat pengaruh positif dan signifikan antara variabel MLSS terhadap kinerja perusahaan, sehingga hipotesis pertama diterima.

Variabel DAR memiliki koefisien sebesar 0,083 dan nilai signifikansi sebesar 0,001. Hal tersebut menunjukkan bahwa terjadi kenaikan pada variabel ROE sebesar 0,083 untuk setiap bertambahnya 1 satuan variabel DAR. Nilai signifikansi sebesar $0,001<0,05$ menunjukkan bahwa varia-bel DAR mempunyai pengaruh yang signifikan. Dengan koefisien positif, maka dapat disimpulkan bahwa terdapat pengaruh positif dan signifikan antara variabel leverage dan kinerja perusahaan. Namun karena hasil penelitian bertentangan dengan hipotesis yang diajukan, sehingga hipotesis kedua tidak diterima.

Variabel VAIC memiliki koefisien sebesar 0,003 dan nilai signifikansi sebesar 0,001. Hal tersebut menunjukkan bahwa terjadi kenaikan pada variabel ROE sebesar 0,003 untuk setiap bertambahnya 1 satuan variabel VAIC. Nilai signifikansi sebesar 0,001<0,05 menunjukkan variabel VAIC mempunyai pengaruh yang signifikan. Dengan koefisien positif, maka dapat disimpulkan bahwa terdapat pengaruh positif dan signifikan antara variabel intellectual capital terhadap kinerja perusahaan, sehingga hipotesis ketiga diterima.

\subsection{Interpretasi Hasil}

\subsubsection{Pengaruh multiple large shareholder structure terhadap kinerja perusahaan}

Berdasarkan teori agensi, masalah yang dihadapi perusahaan tidak melulu membahas antar manajemen dan pemilik, namun juga sesama pemilik perusahaan. Pemilik disini dijelaskan sebagai pemegang saham yang dikategorikan berdasarkan persentase kepemilikan sahamnya. Merunut kembali pada penjelasan Attig et al. (2009), apabila dalam suatu perusahaan terdiri dari beberapa pemilik saham yang memiliki persentase kepemilikan lebih dari 10\%, maka perusahaan tersebut dikatakan memiliki multiple large shareholder structure (MLSS). Permasalahan dalam MLSS adalah bagaimana para pemilik saham saling mempengaruhi dalam pengambilan keputusan mengenai kebijakan untuk proyeksi masa depan perusahaan (Adelopo et al., 2019). Hasil penelitian yang dilakukan penulis menunjukkan terdapat pengaruh positif dari keterlibatan MLSS terhadap kinerja perusahaan sampel yang diteliti, sehingga hipotesis pertama diterima. Hasil penelitian ini mendukung penelitian sebelumnya yang dilakukan Maury \& Pajuste (2005), Attig et al. (2009), dan Luo et al. (2013). Maury \& Pajuste (2005) menjelaskan bahwa pengaruh positif MLSS berhubungan dengan identitas pemilik saham yang tergabung dalam MLSS. Lebih lanjut, MLSS dapat menengahi permasalahan keagenan dengan menjalankan peran vitalnya agar tidak saling berkoalisi untuk memperkaya diri sendiri sehingga dapat merugikan perusahaan. Selain itu, MLSS juga menghindari pengambilalihan hak suara pemilik saham minoritas. Namun, hasil penelitian ini bertentangan dengan hasil penelitian Haryono et al. (2017), Ariesanti \& Soegiarto (2018), dan Hastriyana \& Taqwa (2019) yang menyatakan bahwa MLSS tidak berpengaruh terhadap kinerja perusahaan. Haryono et al. (2017) menilai bahwa kepemilikan saham di Indonesia masih terkonsentrasi sehingga peran MLSS sebagai dewan pengawas pemegang saham terbesar dari suatu perusahaan belum maksimal.

\subsubsection{Pengaruh leverage terhadap kinerja perusahaan}

Hasil penelitian yang dilakukan penulis menjelaskan bahwa leverage berpengaruh positif terhadap kinerja perusahaan. Dengan nilai koefisien sebesar 0,083 untuk variabel leverage yang diukur menggunakan debt to asset ratio, rasio tersebut menunjukkan adanya pengaruh positif pada ROE perusahaan jasa non keuangan yang digunakan sebagai sampel. Namun, hasil tersebut bertentangan dengan hipotesis kedua penulis yang menyatakan bahwa 
leverage berpengaruh negatif terhadap kinerja perusahaan. Dengan demikian hipotesis kedua ditolak. Hal ini senada dengan penelitian yang dilakukan oleh Ludijanto et al. (2014) yang menyatakan bahwa peningkatan rasio debt to asset berimbang dengan adanya peningkatan kinerja perusahaan. Lebih lanjut, Ludijanto et al. (2014) menambah-kan bahwa manajer perusahaan perlu menjaga keadaan tingkat liabilitas perusahaan dalam taraf yang baik sehingga dapat memaksimalkan kenaikan laba yang dapat diperoleh. Dengan demikian, semakin tinggi DAR perusahaan, semakin tinggi perolehan angka rasio kinerja perusahaannya. Sementara penelitian yang dilakukan oleh Isbanah (2015) dan Azis \& Hartono (2017) bertentangan dengan hasil penelitian yang dilakukan penulis. Penelitianpenelitian tersebut membuktikan bahwa leverage berpengaruh negatif terhadap kinerja perusahaan. Isbanah (2015) mengungkapkan bahwa kinerja perusahaan menurun seiring meningkatnya jumlah liabilitas yang dimiliki. Sumber dana yang lebih besar berpotensi memperbesar risiko dari keuntungan yang diperoleh. Risiko yang dapat ditemui adalah dengan melambungnya bunga akibat sumber dana perusahaan yang terlampau tinggi. Akibatnya dapat berujung pada penurunan pendapatan dan peningkatan peluang default atau gagal bayar (Azis \& Hartono, 2017). Namun begitu, perusahaan harus tetap menjaga tingkat DAR perusahaan dalam taraf normal agar tidak terjadi risiko yang tak dapat dihindari, sebab meskipun nilai DAR meningkat tidak akan dapat dirasa manfaatnya jika perusahaan tidak mampu membayar utangnya.

\subsubsection{Pengaruh intellectual capital terhadap kinerja perusahaan}

Hasil penelitian yang dilakukan penulis menunjukkan bahwa intellectual capital berpengaruh positif terhadap kinerja perusahaan. Hasil tersebut mendukung hipotesis penulis yang menyatakan bahwa terdapat pengaruh positif antara VAIC dengan ROE, sehingga hipotesis ketiga diterima. Penelitian ini mendukung penelitian terdahulu yakni milik Chen et al. (2005), Fatima (2012), Sofie et al. (2012), Dwipayani (2014), dan Astuti et al. (2019). Sofie et al. (2012) mengemukakan bahwa investasi sumber dana manusia, yang termasuk dalam komponen intellectual capital, menjadi salah satu faktor penting dalam pengendalian mutu dan kualitas untuk meningkatkan kinerja perusahaan agar banyak investor yang tertarik menanamkan modalnya di perusahaan tersebut. Penelitian ini juga memperkuat adanya keterkaitan antara pelanggan, karyawan, dan pemilik perusahaan, yang semuanya merupakan komponen intellectual capital, dalam menciptakan value added melalui mata rantai kepuasan. Penelitian ini bertentangan dengan penelitian milik Pramelasari (2010) dan Santosa (2012). Pramelasari (2010) menilai bahwa perusahaan di Indonesia belum mampu mengendalikan dan memaksimalkan penggunaan intellectual capital untuk menciptakan value added atau nilai tambah bagi keberlangsungan hidup perusahaan. Lebih lanjut, Santosa (2012) mengungkapkan bahwa penggunaan aset fisik masih lebih unggul dibandingkan aset tak berwujud dalam mendatangkan value added pada perusahaan di Indonesia.

\subsubsection{Pengaruh multiple large shareholder structure, leverage, dan intellectual capital terhadap kinerja perusahaan}

Hasil penelitian yang dilakukan penulis membuktikan secara empiris bahwa variabel multiple large shareholder structure (MLSS), leverage, dan intellectual capital secara simultan berpengaruh terhadap kinerja perusahaan. Berdasarkan pernyataan tersebut, maka hipotesis keempat diterima. Faktor-faktor meningkatnya kinerja perusahaan dapat berasal dari internal seperti manajemen dan pemegang saham; maupun dari faktor gabungan antara pihak internal, eksternal, dan sistem seperti modal intelektual. Pemegang saham yang terkumpul sebagai MLSS dapat memaksimalkan peran pengawasan dalam menjaga keseimbangan 
lingkungan antar pemegang saham di dalam perusahaan sehingga mencegah terjadinya hal yang dapat menurunkan kinerja perusahaan. Manajemen dapat terus memantau tingkat liabilitas yang dimiliki perusahaan agar mampu menggunakan sumber dana secara efisien. Dengan bertambahnya sumber dana, maka perusahaan menjadi lebih leluasa untuk membiayai dana operasionalnya. Hubungan antara pemilik perusahaan, karyawan, serta pelanggan terbukti dapat terus menjalankan siklus kehidupan perusahaan. Komponen kekayaan intelektual semakin memperkuat citra perusahaan. Selain itu, aset tak berwujud seperti sistem yang terintegrasi antar departemen juga menambah nilai bagi perusahaan selain daripada aset fisik.

\section{KESIMPULAN DAN SARAN \\ 4.1 Kesimpulan}

Terdapat pengaruh positif dan signifikan antara MLSS dengan kinerja perusahaan jasa non keuangan yang terdaftar di BEI periode 2014-2018. Pemegang saham kedua terbesar dari perusahaan dapat bertindak sebagai pihak penengah agar tidak terjadi praktik koalisi yang menguntungkan kepentingan pribadi sehingga dapat membuat perusahaan merugi. Leverage berpengaruh positif dan signifikan terhadap kinerja perusahaan. Kenaikan tingkat utang akan membantu meningkatkan penerimaan imbal balik ekuitas perusahaan. Namun, hasil penelitian ini tidak sesuai dengan hipotesis yang diajukan penulis yakni leverage berpengaruh negatif terhadap kinerja perusahaan. Tingkat utang yang terlampau tinggi akan berimbang terhadap risiko yang akan dihadapi, diantaranya risiko default atau gagal bayar. Begitu pun variabel intellectual capital berpengaruh positif dan signifikan terhadap kinerja perusahaan. Aspekaspek kekayaan intelektual yang tidak dapat diukur dengan satuan fisik: human capital, structural capital, dan customer capital mampu memperkuat nilai tambah perusahaan

\subsection{Keterbatasan}

Penelitian ini hanya menggunakan sampel pada sektor perusahaan jasa yang terdaftar di BEI dengan periode penelitian 2014-2018. Untuk mengetahui tingkat MLSS, penelitian ini hanya mengukur dari perbandingan pemegang saham kedua dan pertama terbesar. Penelitian ini masih menggunakan metode VAIC untuk mengukur modal intelektual. Kinerja perusahaan dalam penelitian ini hanya menggunakan rasio profitabilitas ROE.

\subsection{Saran \& Implikasi Penelitian}

Saran bagi peneliti selanjutnya agar memperluas sampel dari sektor lain seperti manufaktur dan juga memperbarui atau menambah periode laporan keuangan yang akan diteliti. Selain itu, dapat digunakan pengukuran lain untuk variabel penelitian seperti menggunakan DER untuk leverage dan ROI untuk kinerja perusahaan. Bagi manajemen dan pemilik perusahaan untuk senantiasa memaksimalkan pengawasan antar pemegang saham agar tidak saling merugikan pihak lain, memperhatikan tingkat liabilitas jangka pendek serta jangka panjang, dan tidak lupa menunjang modal fisik dengan memanfaatkan penggunakan intellectual capital dalam memperoleh nilai tambah bagi perusahaan.

\section{REFERENSI}

Adelopo, I., Yinusa, G., \& Rufai, I. (2019). The Impacts of Multiple Large Ownership Structure on Board Independence. Int. J. Accounting, Auditing and Performance Evaluation, 15(1), 1-30. 
Aldin, Ihya Ulum (2019). Agung Podomoro Land Dapat Dana Segar Rp 2,6 Triliun untuk Bayar Utang. (Online), (https://katadata.co.id/berita/2019/09/26/agung-podomoro-landdapat-dana-segar-rp-26-triliun-untuk-bayar-utang, diakses 28 Maret 2020).

(2019). Terlilit Utang, Bakrie Telecom Berniat Transformasi Bisnis. (Online),(https://katadata.co.id/berita/2019/07/05/terlilit-utang-bakrie-telecom-berniattransformasi-bisnis, diakses 28 Maret 2020).

Ariesanti, R. A., \& Soegiarto, D. (2018). Pengaruh Struktur Modal, Struktur Kepemilikan, dan Ukuran Perusahaan Terhadap Nilai Perusahaan (Studi pada Perusahaan Properti yang Terdaftar di BEI Tahun 2012-2015). Buletin Ekonomi Manajemen, Ekonomi Pembangunan, Akuntansi, 16(1).

Astuti, M., Sarda, S., \& Muchran, M. (2019). Pengaruh Intellectual Capital Terhadap Profitabilitas pada Perusahaan Manufaktur yang Terdaftar di Bursa Efek Indonesia. Profitability: Jurnal Ilmu Manajemen, 3(2), 103-118.

Attig, N., El Ghoul, S., \& Guedhami, O. (2009). Do Multiple Large Shareholders Play A Corporate Governance Role? Evidence from East Asia. Journal of Financial Research, 32(4), 395-422.

Azis, A. \& Hartono, U. (2017). Pengaruh Good Corporate Governance, Struktur Modal, dan Leverage Terhadap Kinerja Keuangan Perusahaan Pada Sektor Pertambangan yang Terdaftar di Bursa Efek Indonesia Tahun 2011-2015. Jurnal Ilmu Manajemen (JIM), 5(3).

Chen, M. C., Cheng, S. J., \& Hwang, Y. (2005). An Empirical Investigation of The Relationship Between Intellectual Capital and Firms' Market Value and Financial Performance. Journal of Intellectual capital.

Dwipayani, Chrisnatty Chandra (2014). Pengaruh Intellectual Capital Terhadap Profitabilitas dan Kinerja Pasar (Studi Empiris pada Perusahaan Perdagangan dan Jasa). Skripsi tidak diterbitkan. Semarang: Universitas Diponegoro.

Fatima, Hasna (2012). Analisis Pengaruh Modal Intelektual Terhadap Kinerja Perusahaan di Indonesia. Skripsi tidak diterbikan. Depok: Universitas Indonesia.

Goh, P. C., \& Lim, K. P. (2004). Disclosing Intellectual Capital in Company Annual Reports: Evidence from Malaysia. Journal of Intellectual capital.

Haryono, S. A., Fitriany, F., \& Fatima, E. (2017). Pengaruh Struktur Modal dan Struktur Kepemilikan Terhadap Nilai Perusahaan. Jurnal Akuntansi dan Keuangan Indonesia, 14(2), 119-141.

Hastriyana, A., \& Taqwa, S. (2019). Pengaruh Multiple Large Shareholder Terhadap Nilai Perusahaan. Jurnal Eksplorasi Akuntansi, 1(3), 1080-1095.

Helfert, Erich A. (1994). Techniques of Financial Analysis: A Practical Guide to Managing and Measure Business Performance. Chicago: Irwin Professional Pub.

Herman, N. W. (2016). Analisis Pengaruh Kepemilikan Manajerial, Kepemilikan Institusional, Leverage, dan Intellectual Capital Terhadap Kinerja Perusahaan. Skripsi tidak diterbitkan. Semarang: Universitas Negeri Semarang.

Hillman, A.J., Cannella, A.A. \& Paetzold, R.L. (2000) The Resource Dependence Role of Corporate Directors: Strategic Adaptation of Board Composition In Response To Environmental Change. Journal of Management Studies, 37(2), 235-256.

Isbanah, Y. (2015). Pengaruh Esop, Leverage, And Ukuran Perusahaan Terhadap Kinerja Keuangan Perusahaan Di Bursa Efek Indonesia. Jurnal Riset Ekonomi dan Manajemen, 15(1), 28-41.

Kesumawati, N, Retta, A.M. \& Sari, N. (2018). Pengantar Statistika Penelitian. Depok: Rajawali Pers. 
Ludijanto, S.E., Handayani, S.R., \& Hidayat, R.R. (2014). Pengaruh Analisis Leverage Terhadap Kinerja Keuangan Perusahaan (Studi pada Perusahaan Property dan Real Estate yang listing di BEI Tahun 2010-2012). Jurnal Administrasi Bisnis, 8(1).

Luo, J. H., Wan. D.F., Cai, D. \& Liu, H. (2013). Multiple Large Shareholder Structure and Governance: The Role of Shareholder Numbers, Contest for Control, and Formal Institutions in Chinese Family Firms. Management and Organization Review, 9(2), 265294.

Maury, B., \& Pajuste, A. (2005). Multiple Large Shareholders and Firm Value. Journal of Banking \& Finance, 29(7), 1813-1834.

Orniati, Y. (2009). Laporan Keuangan sebagai Alat untuk Menilai Kinerja Keuangan. Jurnal Ekonomi Bisnis, 14(3), 206-213.

Pramelasari, Y. M. (2010). Pengaruh Intellectual Capital Terhadap Nilai Pasar dan Kinerja Keuangan Perusahaan. Skripsi tidak diterbitkan. Semarang: Universitas Diponegoro.

Pearce, J.A. \& Zahra, S.A. (1992). Board Composition From A Strategic Contingency Perspective. Journal of Management Studies, 29(4), 411-438.

Putri, Halimah Dwi (2015). Pengaruh Kinerja Keuangan Terhadap Nilai Perusahaan dengan Pengungkapan Corporate Social Responsibility dan Good Corporate Governace sebagai Variabel Pemoderasi: Studi pada Perusahaan Manufaktur di Bursa Efek Indonesia 20112013. Skripsi tidak diterbitkan. Malang: Universitas Islam Negeri Maulana Malik Ibrahim.

Rust, R. T., Zahorik., A. J., \& Keiningham, T.L. (1994). Return On Quality: Measuring The Financial Impact of Your Company's Quest for Quality. Chicago: Probus Pub. Co.

Sofie, S., Prihartini, A., \& Liana, R. (2012). Intellectual Capital Terhadap Nilai Pasar Dan Kinerja Keuangan Perusahaan Dengan Value Added Intellectual Capital (Studi Pada Perusahaan Manufaktur di Bursa Efek Indonesia Tahun 2008-2011). Jurnal Informasi, Perpajakan, Akuntansi, Dan Keuangan Publik, 7(2), 43-54.

Sudaryono (2018). Metodologi Penelitian. Depok: Rajawali Pers.

Ulum, Ihyaul (2017). Intellectual Capital: Model Pengukuran, Framework Pengungkapan dan Kinerja Organisasi. Malang: UMM Press. 